\title{
Factors related to permanent disability employment on patients fewer than 62 years operated by open heart surgery
}

\author{
R MartinezSanz ${ }^{1,2}$, R ávalos ${ }^{*}$, L Perdomo², ME Alonso², F Benitez², JJ Jiménez ${ }^{1}$, J Montoto ${ }^{1}$, PC Prada ${ }^{1}$, P Garrido ${ }^{1}$, \\ R de la Llana ${ }^{1,2}$, M Brouard', $^{1}$ JL Iribarren ${ }^{1}$ \\ From World Society of Cardiothoracic Surgeons 25th Anniversary Congress, Edinburgh \\ Edinburgh, UK. 19-22 September 2015
}

\section{Background}

The quality of life after cardiac surgery greatly improves the reincorporation into the usual job, although not always in the same proportion.

\section{Objective}

Our proposal is to identify factors that complicate the return to work after open heart surgery.

\section{Materials and method}

All the patients younger of 62 years old who underwent open heart surgery between the years 2010 and 2012 were studied. Perioperative variables were collected: preoperative functional status, LVEF, type of intervention, type of job (employee or self-employed person) and permanent incapacity (PI) for employment through a review of their medical history.

\section{Results}

A cohort of 204 patients was studied. Age $51+/-9$ years; 156 (76,5\%) were male; Logistic Euroscore (LE) of 5.1 +/8.4, LVEF $58+/$ - 11. Surgery was 86 (42.2\%) CABG, $79(38.7 \%)$ valvular, $16(7.8 \%)$ combined surgery and $23(11.3 \%)$ others. 28 (13.7\%) were self-employed. 15 of them already had a PI at the time of surgery. Patients with PI presented a LE of $6.7+/-3.9$ Vs. $11+/-5(\mathrm{p}=0.006)$; age $53+/-6$ vs $48+/-10(\mathrm{p}<0.001)$, with no difference in LVEF. There were more PI among women (57\%) than male $41 \%(p=0.046)$. There was a higher percentage of valvular surgery in women. Higher number of CABG and valvular surgery was associated with PI $(\mathrm{p}=0.015)$.

${ }^{1}$ Complejo Hospitalario Universitario de Canarias, Tenerife, Spain Full list of author information is available at the end of the article

\section{Conclusions}

Permanent work cessation activity after open-heart surgery was statistically determined with an older age, comorbidity, female gender and type of intervention. Valve surgery, the number of valves operated or higher number of bypasses increase the probability of PI.

\section{Authors' details}

${ }^{1}$ Complejo Hospitalario Universitario de Canarias, Tenerife, Spain.

${ }^{2}$ Universidad de La Laguna, Tenerife, Spain.

Published: 16 December 2015

\section{doi:10.1186/1749-8090-10-S1-A311}

Cite this article as: MartinezSanz et al: Factors related to permanent disability employment on patients fewer than 62 years operated by open heart surgery. Journal of Cardiothoracic Surgery 2015 10(Suppl 1): A311.
Submit your next manuscript to BioMed Central and take full advantage of:

- Convenient online submission

- Thorough peer review

- No space constraints or color figure charges

- Immediate publication on acceptance

- Inclusion in PubMed, CAS, Scopus and Google Scholar

- Research which is freely available for redistribution

Submit your manuscript at www.biomedcentral.com/submit
( Biomed Central 